\title{
PENGARUH WORK-FAMILY CONFLICT DAN DUKUNGAN ORGANISASI TERHADAP KEPUASAN KERJA \& TURNOVER INTENTION PADA THE SAMAYA
}

\author{
I Wayan Pide Aditra Salinas ${ }^{1}$ \\ I Gusti Ayu Ketut Giantari ${ }^{2}$ \\ ${ }^{1,2}$ Fakultas Ekonomi dan Bisnis Universitas Udayana, Bali, Indonesia \\ email: pideaditra@gmail.com
}

\begin{abstract}
ABSTRAK
Sumber daya manusia senantiasa melekat pada setiap perusahaan sebagai faktor penentu keberadaan.Tujuan penelitian adalah menganalisis pengaruh work-family conflict dan dukungan organisasi terhadap kepuasan kerja juga menganalisis pengaruh work-family conflict, dukungan organisasi dan kepuasan kerja terhadap turnover intention. Sampel ditentukan sebanyak66orang dengan teknik sampling jenuh. Pengumpulan data dilakukan dengan menyebar kuesioner secara langsung kepada karyawan The Samaya Seminyak Bali dan dianalisis menggunakan statistik dekriptif rata-rata hitung serta statistik deskriptif berupa uji asumsi klasik dan analisis jalur.Hasil analisis data menunjukkan bahwa variabel work-family conflict berpengaruh negatif dan dukungan kerja berpengaruh positif terhadap kepuasan kerja. Variabel dukungan organisasi dan kepuasan kerja berpengaruh negatif terhadap turnover intention.Work-family conflict berpengaruh positif terhadap turnover intention.
\end{abstract}

Kata kunci : Turnover intention, kepuasan kerja, dukungan organisasi.

\begin{abstract}
Human resources are always attached to every company as a determinant of existence. The purpose of the study was to analyze the effect of work-family conflict and organizational support on job satisfaction as well as analyze the effect of work-family conflict, organizational support and job satisfaction on turnover intention. The sample was determined by 66 people with saturated sampling techniques. Data collection was done by distributing questionnaires directly to employees of The Samaya Seminyak Bali and analyzed using calculative descriptive statistics and descriptive statistics in the form of classic assumption tests and path analysis. The results of data analysis showed that workfamily conflict variables had a negative effect and work support had a positive effect on job satisfaction. Variables of organizational support and job satisfaction have a negative effect on turnover intention. Work-family conflict has a positive effect on turnover intention.

Keyword : Turnover intention, job satisfaction, organizational support
\end{abstract}




\section{PENDAHULUAN}

Sumber daya manusia senantiasa melekat pada setiap perusahaan sebagai faktor penentu keberadaan dan berperan dalam memberikan kontribusi ke arah pencapaian tujuan perusahaan secara efektif dan efisien. Perusahaan membutuhkan sumber daya manusia yang handal dan berkualitas sehingga perusahaan harus dapat mengelola dan memperhatikan sumber daya manusia dengan sebaik mungkin (Waspodo dkk., 2013). Sumber daya manusia mempunyai peranan penting dalam perusahaan seperti membuat perencanaan, mengatur, mengolah, dan mengontrol setiap kegiatan perusahaan (Tintami et al., 2012).

Keberadaan karyawan (SDM) perlu dikelola dengan baik agar dapat memberikan kontribusi positif pada kemajuan organisasi. SDM memiliki tanggung jawab dan peran sebagai motor penggerak organisasi dalam mencapai tujuan organisasi, namun seringkali mengalami kegagalan dalam memerankan tugas dan tanggung jawab yang berujung pada turunnya kinerja karyawan. Karyawan yang memiliki penurunan kinerja biasanya mulai berpikir untuk berhenti bekerja di perusahaan yang sekarang dan melirik perusahaan lain. Organisasi perlu melakukan antisipasi menghadapi kemungkinan adanya niat karyawan yang ingin pindah ke perusahaan lain (Rindi, 2014).

Tingginya keinginan karyawan untuk berpindah (turnover intention) pada suatu perusahaan merupakan permasalahan besar yang dihadapi oleh seluruh perusahaan yang berdampak pada aktifitas dan produktifitas perusahan. Perusahaan akan kebingungan jika mengetahui karyawannya memiliki keinginan untuk keluar dari perusahaan, apalagi karyawan tersebut dapat digolongkan karyawan yang memiliki dedikasi yang tinggi terhadap perusahaan dan memiliki kualitas kerja yang baik. Banyak kerugian yang akan ditanggung oleh perusahaan jika karyawan memiliki keinginan untuk keluar dari perusahaan. Hal utama yang akan menjadi permasalahan dalam perusahaan adalah dana yang dikeluarkan perusahaan untuk melakukan proses rekrutmen karyawan sampai dengan berbagai pelatihan yang diberikan kepada karyawan akan sia-sia (Wulandari dan Adnyani, 2016).

Turnover intention dapat timbul dikarenakan karyawan merasa kesulitan didalam menghadapi Work-family conflict yang merupakan konflik peran ganda yang menuntut seseorang membagi perannya antara keluarga dan pekerjaan. Adanya peran ganda tersebut mengakibatkan karyawan harus memilih untuk fokus pada pekerjaanya atau keluarga (Tariana dan Wibawa, 2016).Hasil penelitian Wulandari dan Adnyani (2016) menunjukkan bahwa work family conflict berpengaruh positif terhadap turnover intention. Artinya tingginya work family conflict yang dirasakan oleh karyawan dapat mempengaruhi keinginan keluar dari perusahaan, sehingga semakin tinggi work family conflict maka semakin tinggi pula turnover intention yang dirasakan karyawan. Adapun indikator yang digunakan untuk mengukur work family conflict dalam penelitian ini adalah time based conflict, strain based conflict, dan behavior-based conflict.

Hasil observasi dan wawancara terhadap kepala HRD The Samaya Seminyak Bali ditemukan adanya indikasi masalah terkait dengan turnover intention yang disebabkan karena penurunan kepuasan kerja yang dirasakan oleh 
karyawan pada Samaya Seminyak Bali. Hal ini didukung dalam penelitian Gliselli et al. (2001) yang mengemukakan bahwa variabel yang berpengaruh secara kuat terhadap turnover intention salah satunya adalah kepuasan kerja. Sejalan dengan itu, penelitian yang dilakukan Yucel (2012) dan Sartika (2014) menemukan adanya hubungan negatif antara turnover intention dengan kepuasan kerja. Hal ini berarti ketika tingkat kepuasan kerja meningkat maka akan menurunkan tingkat turnover intention yang ada karyawan.

Hasil observasi awal yang telah dilakukan peneliti terhadap 20 orang karyawan The Samaya Seminyak Bali, juga mendapatkan hasil bahwa terdapat beberapa karyawan yang memiliki niat untuk meninggalkan perusahaan karena keinginannya sendiri. Karyawan yang mempunyai niat untuk meninggalkan perusahaan karena niatnya sendiri disebabkan karena karyawan tersebut berpindah tempat tinggal ataupun telah mendapatkan kesempatan kerja lebih baik ditempat lain. Kemudian terdapat juga karyawan wanita yang memiliki niat untuk meninggalkan perusahaan dikarenakan kesulitan di dalam membagi waktu antara keluarga atau pekerjaan yang cenderung lebih menghabiskan banyak waktu di kantor dibandingkan dengan keluarganya. Beberapa karyawan juga memiliki keinginan keluar dari perusahaan dikarenakan beban kerja yang tidak sesuai dengan keahlian karyawan tersebut, gaji yang tidak sepadan dengan kinerja karyawan, kurangnya kesempatan dari karyawan untuk memperoleh kenaikan jabatan, kurangnya bantuan dari pimpinan saat karyawan mengalami kesulitan kerja dan hubungan kurang baik antara karyawan dengan rekan kerjanya.

Penelitian ini dilakukan pada hotel The Samaya Seminyak Bali. The Samaya Seminyak Bali adalah perusahaan yang berlokasi di jalan Laksamana, Seminyak Beach, Kuta, Seminyak dan bergerak di bidang jasa akomodasi, bar, spa,\&restaurant. Hotel ini memiliki 52 unit villa dengan private pool,public pool, public hall, restaurant,gym \& spa dengan total karyawan tetap sejumlah 66 orang yang terdiri dari bagian FO 11 orang, HK 23 orang, F\&B Product 10 orang, F\&B Service 6 orang, Security 4 orang, Accounting 2 orang, Engineering 4 orang, GM 1 orang \& Therapist spa 5 orang. The Samaya Seminyak Bali dijadikan sebagai lokasi penelitian karena pertimbangan berdasarkan wawancara dari kepala HRD diperoleh informasi bahwa The Samaya Seminyak Bali inipada tahun 2016 mengalami masalah turnover yang cukup tinggi terhadap karyawan tetapnya.

Tabel 1.

Data Turnover Karyawan The Samaya Periode Tahun 2015 - 2018

\begin{tabular}{cccccc}
\hline Tahun & $\begin{array}{c}\text { Jumlah } \\
\text { karyawan } \\
\text { tetap awal tahun } \\
\text { (orang) }\end{array}$ & $\begin{array}{c}\text { Jumlah } \\
\text { karyawan } \\
\text { tetap akhir } \\
\text { tahun (orang) }\end{array}$ & $\begin{array}{c}\text { Rata-rata } \\
\text { karyawan } \\
\text { tetap }\end{array}$ & $\begin{array}{c}\text { Karyawan } \\
\text { keluar } \\
\text { (orang) }\end{array}$ & $\begin{array}{c}\text { Karyawan } \\
\text { keluar (\%) }\end{array}$ \\
\hline 2015 & 83 & 79 & 81 & 4 & 5.06 \\
2016 & 77 & 72 & 74.5 & 5 & 6.94 \\
2017 & 71 & 70 & 70.5 & 1 & 1.42 \\
2018 & 70 & 66 & 68 & 4 & 6,06 \\
\hline
\end{tabular}

Sumber: The Samaya Seminyak Bali, 2018

Dari data turnover Tabel 1. terlihat bahwa jumlah karyawan tetap pada periode tahun 2016 terjadi penurunan. Akhir tahun 2016 The Samaya Seminyak 
Bali memiliki jumlah karyawan tetap sebanyak 72 orang. Tercatat 5 orang atau 6,94 persen dari jumlah karyawan tetap yang menyatakan mundur dari pekerjaannya, lalu mengalami penurunan pada tahun 2017 dan kemudian mengalami kenaikan lagi pada akhir tahun 2018 yaitu terdapat 4 orang karyawan atau sebanyak 6,06 persen dari jumlah karyawan tetap The Samaya Seminyak Bali yang menyatakan mundur dari pekerjaan. Jumlah ini melampaui batas maksimal yang ditetapkan The Samaya Seminyak Bali sehingga menarik untuk diteliti terkait permasalahan sumber daya manusianya. Dengan alasan tersebut maka penelitian ini dilakukan pada karyawan The Samaya Seminyak Bali.

Berdasarkan latar belakang masalah di atas, maka yang menjadi pokok permasalahan dalam penelitian ini antara lain: 1)Bagaimanakah pengaruh Workfamily conflict terhadap kepuasan kerja karyawan pada The Samaya Seminyak Bali ?2)Bagaimanakah pengaruh dukungan organisasi terhadap kepuasan kerja karyawan pada The Samaya Seminyak Bali ? 3)Bagaimanakah pengaruh Workfamily conflict terhadap terhadap turnover intention pada The Samaya Seminyak Bali ? 4)Bagaimanakah pengaruh dukungan organisasi terhadap turnover intention pada The Samaya Seminyak Bali ? 5)Bagaimanakah pengaruh kepuasan kerja terhadap turnover intention pada The Samaya Seminyak Bali ?. Berdasarkan rumusan masalah diatas, maka tujuan dari penelitian ini adalah: 1)Untuk menganalisis pengaruh Work-family conflict terhadap kepuasan kerja karyawan pada The Samaya Seminyak Bali, 2)Untuk menganalisis pengaruhdukungan organisasi terhadap kepuasan kerja karyawan pada The Samaya Seminyak Bali, 3)Untuk menganalisis pengaruh Work-family conflict terhadap turnover intention pada The Samaya Seminyak Bali, 4)Untuk menganalisis pengaruh dukungan organisasi terhadap turnover intention pada The Samaya Seminyak Bali, 5)Untuk menganalisis pengaruh kepuasan kerja terhadap turnover intention pada The Samaya Seminyak Bali.

Berdasarkan penelusuran kajian pustaka dan hasil - hasil penelitian terdahulu diketahui bahwa turnover intentionkaryawan dapat dipengaruhi oleh kepuasan kerja, work family conflictdan dukungan organisasi. Semakin tinggi work family conflict yang dirasakan oleh karyawan, maka kepuasan kerja karyawan akan semakin menurun dan semakin tinggi dukungan organisasi yang diterima karyawan, maka kepuasan kerja yang dirasakan karyawan akan semakin meningkat. Selanjutnya, semakin tinggi work-family conflict yang dirasakan oleh karyawan dapat mempengaruhi meningkatnya keinginan karyawan untuk keluar dari perusahaan. Namun, semakin tinggi dukungan organisasi yang diterima karyawan, maka akan semakin mengurangi keinginan karyawan untuk keluar dari perusahaan. Begitu pula semakin tinggi kepuasan kerja karyawan, maka akan semakin mengurangi keinginan karyawan untuk keluar dari perusahaan. Berdasarkan kajian penelitian terdahulu tersebut, maka model penelitian dapat digambarkan seperti pada Gambar 1.

Work-family conflict yang merupakan konflik peran ganda yang menuntut seseorang membagi perannya antara keluarga dan pekerjaan. Adanya peran ganda tersebut mengakibatkan karyawan harus memilih untuk fokus pada pekerjaanya atau keluarga (Tariana dan Wibawa, 2016). Wulandari dan Adnyani (2016) dalam penelitiannya menyimpulkan bahwa work family conflict berpengaruh negatif 
terhadap kepuasan kerja pada karyawan. Hal ini menunjukkan bahwa semakin tinggi work family conflict yang dirasakan, maka kepuasan kerja karyawan akan semakin rendah.

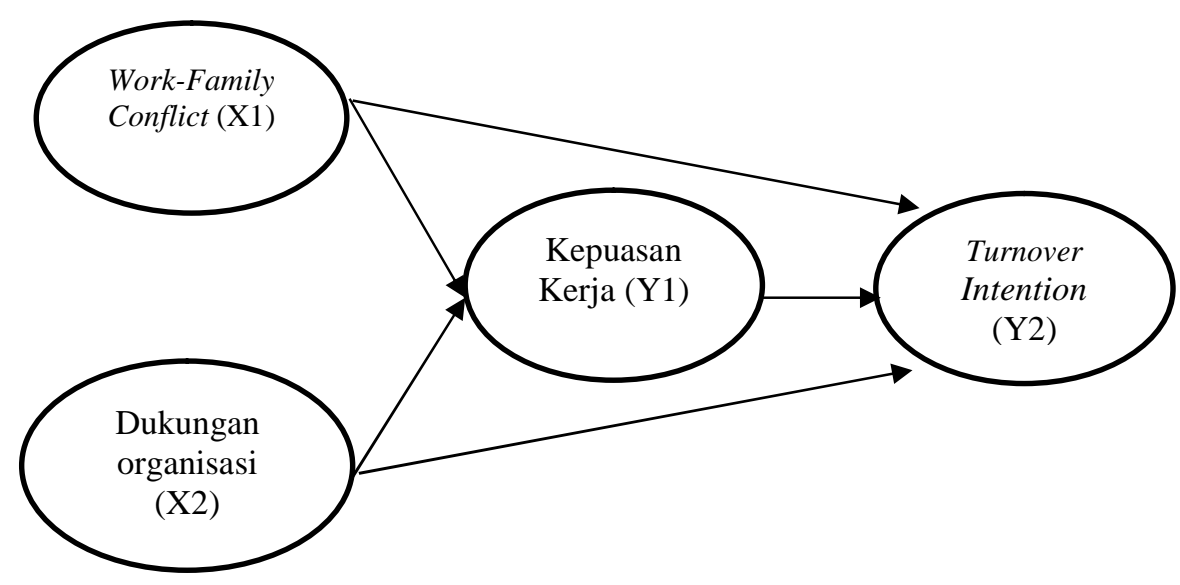

Sumber: Data Diolah, 2019

\section{Gambar 1. Kerangka Konseptual}

Hasil penelitian serupa oleh Laksmi dan Hadi (2012), Retnaningsih dan Musadieq (2016), Ariana dan Riana (2016) serta Afrilia dan Utami (2018) juga memperoleh hasil bahwa ada pengaruh negatif dan signifikan antara work family conflict terhadap kepuasan kerja karyawan. Hasil penelitian tersebut menunjukkan ketika karyawan merasa bahwa tuntutan peran kerja mereka mengganggu pemenuhan peran keluarga maka mempengaruhi sikap mereka terhadap pekerjaan, yang selanjutnya dapat mengakibatkan kepuasan kerja berkurang.

Berdasarkan hasil penelitian yang telah diuraikan maka dapat dirumuskan hipotesis penelitian sebagai berikut.

$\mathrm{H}_{1}$ :Work-family conflict berpengaruh negatif terhadap kepuasan kerja karyawan

Dukungan organisasi berpengaruh positif dan signifikan terhadap kepuasan kerja, ketika karyawan merasakan kondisi pekerjaan yang menyenangkan mereka akan memiliki kepuasan kerja yang tinggi (Kuo et al., 2015). Organisasi yang memperlakukan karyawan dengan baik melalui pemberian penghargaan finansial maupun non finasial maka karyawan yang bersangkutan akan merasakan dukungan organisasi, sehingga akan memiliki kepuasan kerja yang lebih tinggi dan membalasnya dengan kinerja yang baik (Yih \& Htaik 2011). Menurut Ehsani el al. (2013) organisasi yang memiliki hubungan humanistik dengan stafnya (dukungan organisasi) akan memiliki kepuasan kerja yang tinggi. Pathak (2012) menyatakan ketika karyawan merasa bahwa organisasi peduli terhadap kesejahteraan dan opini mereka, maka karyawan akan merasakan kepuasan kerja. Hasil daridukungan organisasi yang baik salah satunya adalah kepuasan kerja karyawan (Dawley et al., 2010).

Hasil analisis Dhyana dan Adnyani (2018) menunjukkan bahwa dukungan organisasi berpengaruh positif dan signifikan terhadap kepuasan kerja. Hal ini 
memiliki makna bahwa semakin banyak dukungan organisasi yang diberikan terhadap karyawan, maka akan semakin tinggi pula kepuasan kerja yang ditunjukkan oleh karyawan. Begitu pula sebaliknya, semakin sedikit dukungan organisasi yang diberikan kepada karyawan maka semakin rendah tingkat kepuasan kerja karyawan pada organisasi tersebut. Hasil penelitian Dewi dan Dewi (2018) memperoleh hasil bahwa terdapat pengaruh dukungan organisasi yang positif dan signifikan terhadap kepuasan kerja, dengan demikian dapat dijelaskan bahwa semakin tinggi dukungan organisasi maka kepuasan kerja akan semakin tinggi dirasakan, dan sebaliknya semakin rendah dukungan organisasi maka akan berdampak pada penurunan kepuasan kerja yang dirasakan. Penelitian serupa oleh Dewi dan Utama (2015) memperoleh hasil bahwa terdapat pengaruh positif dan signifikan dari variabel dukungan organisasi terhadap kepuasan kerja.

Berdasarkan penelitian-penelitian terdahulu, dapat dirumuskan hipotesis sebagai berikut :

$\mathrm{H}_{2}$ : Dukungan organisasi berpengaruh positif terhadap kepuasan kerja karyawan.

Work-family conflict dapat didefinisikan sebagai bentuk konflik peran dimana tuntutan peran dari pekerjaan dan keluarga secara mutual tidak dapat disejajarkan dalam beberapa hal (Buhali dan Margaretha, 2013). Hasil penelitian Wulandari dan Adnyani (2016) menunjukkan bahwa work family conflict berpengaruh positif terhadap turnover intention. Artinya tingginya work family conflict yang dirasakan oleh karyawan dapat mempengaruhi keinginan keluar dari perusahaan, sehingga semakin tinggi work family conflict maka semakin tinggi pula turnover intention yang dirasakan karyawan.

Ghayyur dan Jamal (2012) dalam penelitiannya mengatakan bahwa work family conflict berpengaruh positif dan signifikan dengan turnover intention. Lathifah dan Rohman (2014) berpendapat bahwa Work-family conflict berpengaruh positif terhadap turnover intention. Berdasarkan sisi Work-family conflict, seseorang yang memiliki jam kerja yang lama maka akan merasa kesulitan dalam menyeimbangkan tuntutan atas pekerjaan dan keluarga sehingga timbul tekanan atau stres dalam dirinya dan berdampak pada menurunnya kepuasan kerja dan keinginan untuk keluar atau pindah dari organisasi tersebut (Amelia, 2010). Penelitian yang dilakukan oleh Blomme et al. (2010) dan Ngadiman dkk. (2014) juga mengemukakan bahwa Work-family conflict berpengaruh positif dengan turnover intention. Dengan adanya literatur yang teoritis dan bukti yang empiris, maka di dapat hipotesis sebagai berikut :

$\mathrm{H}_{3}$ : Work-family conflict berpengaruh positif terhadap Turnover intention

Perryer et al. (2010) mengatakan POS (Perceived organizational support) atau dukungan organisasi memiliki pengaruh negatif terhadap turnover intention. Penelitian lain dari Newman et al. (2015) mengemukakan bahwa dukungan organisasi berpengaruh negatif dengan turnover intention. Hasil pengujian penelitian Fahrizal dan Utama (2017) menemukan bahwa dukungan organisasi memiliki pengaruh negatif dan signifikan terhadap turnover intention. Artinya dukungan organisasi yang tinggi akan menurunkan turnover intention karyawan. Hal ini berarti bahwa dukungan organisasi yang tinggi cenderung menurunkan keinginan karyawan untuk meninggalkan perusahaan. Rhoades et al. (2002) dan 
Maertz et al. (2007) juga menyatakan bahwa terjadi hubungan negatif Antara dukungan organisasi dengan turnover intention.

Hasil penelitian serupa oleh Satriya (2018) menunjukkan hasil bahwa terdapat pengaruh percieved organizational support (POS) terhadap intensi turnover yang menunjukkan adanya hubungan negatif, dimana dapat diartikan bahwa semakin tinggi tingkat percieved organizational support (POS) maka semakin rendah tingkat intensi turnover seorang karyawan. Berdasarkan hasil penelitian yang telah diuraikan sebelumnya dapat dirumuskan hipotesis sebagai berikut.

$\mathrm{H}_{4}$ : Dukungan organisasi berpengaruh negatif terhadap Turnover intention

Turnover intention dapat berupa pengunduran diri, perpindahan keluar unit organisasi, pemberhentian atau kematian anggota organisasi, keinginan untuk meninggalkan suatu organisasi umumnya didahului oleh niat karyawan yang dipicu antara lain oleh ketidakpuasan karyawan terhadap pekerjaan serta rendahnya komitmen karyawan untuk mengikatkan diri pada organisasi (Jimad, 2011). Tariana dan Wibawa (2016) menyatakan bahwa kepuasan kerja berpengaruh negatif dan signifikan terhadap turnover intention. Hal ini menunjukkan bahwa semakin tinggi tingkat kepuasan kerja karyawan maka semakin rendah turnover intention yang dirasakan karayawan pada perusahaan tersebut. Sejalan dengan itu, penelitian yang dilakukan Yucel (2012) dan Sartika (2014) menemukan adanya hubungan negatif antara turnover intention dengan kepuasan kerja. Hal ini berarti ketika tingkat kepuasan kerja meningkat maka akan menurunkan tingkat turnover intention yang ada karyawan. Beberapa penelitian lainnya juga mengidentifikasi hubungan negatif antara kepuasan kerja dan turnover intention. Jaramilo et al. (2006) dan Novliadi (2007) menemukan bahwa kepuasan kerja berpengaruh untuk menurunkan keinginan untuk meninggalkan perusahaan. Lai et al. (2012) dan Ucho et al. (2012) mendapatkan variabel kepuasan berpengaruh negatif dan signifikan terhadap turnover intention. Hal ini senada dengan pendapat Salleh (2012); Islam (2012); Mahdi, (2012); dan Ardana, dkk. (2012:148) bahwa kepuasan kerja mempunyai hubungan negatif dengan turnover intention atau keinginan karyawan untuk pindah pekerjaan. Berdasarkan hasil penelitian yang telah diuraikan sebelumnya dapat dirumuskan hipotesis sebagai berikut.

$\mathrm{H}_{5}$ : Kepuasan kerja berpengaruh negatif terhadap turnover intention

\section{METODE PENELITIAN}

Penelitian ini menggunakan pendekatan kuantitatif berbentuk asosiatif, yaitu menganalisis hubungan Work-family conflict dan dukungan organisasi terhadap kepuasan kerja dan turnover intention pada The Samaya Seminyak Bali. Lokasi penelitian dilakukan di The Samaya Seminyak Bali yang berlokasi di jalan Laksamana, Seminyak Beach, Kuta, Seminyak. Ruang lingkup dalam penelitian ini antara lain, Work-family conflict dan dukungan organisasi terhadap kepuasan kerja dan turnover intention. Alasan yang melatarbelakangi peneliti melakukan penelitian pada The Samaya Seminyak Bali adalah ditemukannya masalah 
mengenai kepuasan kerja dan turnover intentionpadakaryawan.Subjek dari penelitian ini adalah karyawan tetap pada The Samaya Seminyak Bali.Objek dalam penelitian ini adalah kepuasan kerja dan turnover intention.Berdasarkan pada pokok masalah yang telah dirumuskan serta hipotesis yang diajukan, maka variabel-variabel dalam penelitian ini adalah Variabel bebas atau independent variable dalam penelitian ini adalah Work-family conflict $\left(\mathrm{X}_{1}\right)$ dan dukungan organisasi $\left(\mathrm{X}_{2}\right)$.Variabel terikat atau dependent variable dalam penelitian ini adalah kepuasan kerja (Y1) dan turnover intention (Y2).

Turnover intention secara singkatnya dapat dikatakan sebagai niatan karyawan yang berada dalam satu perusahaan ingin berpindah ke perusahaan lain. Indikator yang digunakan untuk mengukur variabel turnover intentiondalam penelitian ini mengacu pada indikator Setiawan (2016) yang terdiri dari: 1) Munculnya keinginan meninggalkan perusahaan 2) Munculnya keinginan untuk mencari pekerjaan baru 3) Keinginan untuk meninggalkan perusahaan dalam beberapa bulan mendatang. Kepuasan kerja merupakan perbandingan antara apa yang dirasakan dan diperoleh seseorang dengan apa yang seharusnya dia rasakan dan dia peroleh dari pekerjaan, wujud dari kepuasan kerja adalah antara lain rajin masuk kerja, tingkat absensi rendah, tidak ada keluh kesah, dan jumlah karyawan yang berhenti bekerja secara sepihak relatif rendah. Indikator yang digunakan untuk mengukur variabel kepuasan kerja dalam penelitian ini mengacu pada indikator Azeem (2010), yaitu sebagai berikut: 1) Gaji 2) Pekerjaan itu sendiri3)Promosi4)Atasan (supervisor) 5) Rekan kerja.

Work-family conflictmerupakan konflik peran antara pekerjaan terhadap keluarga karena berbagai situasi yang susah didalam hal memproritaskan pekerjaan maupun keluarga. Indikator Work-family conflict dalam penelitian ini mengacu pada indikator menurut Adekola (2010) yaitu terdiri dari: 1)Time based conflict 2)Strain based conflict 3)Behavior-based conflict. Dukungan organisasi merupakan penilaian karyawan terhadap dukungan yang diberikan oleh perusahaan kepada karyawannya. Indikator yang digunakan untuk mengukur variable persepsi dukungan organisasional dalam penelitian ini mengacu pada indikator yang digunakan oleh Fahrizal dan Utama (2017) yaitu sebagai berikut: 1)Perusahaan menghargai kontribusi karyawan 2) Organisasi memberi pengakuan kerja 3)Organisasi menanggapi keluhan karyawan 4) Organisasi memberikan bantuan bagi karyawan 5) Organisasi peduli dengan kesejahteraan karyawan 6)Organisasi memperhatikan karyawan yang bekerja dengan baik 7) Organisasi menunjukan prestasi karyawan kepada karyawan lain.

Data Kualitatif, yaitu data yang dinyatakan dalam bentuk kata, kalimat, dan skema (Sugiyono, 2014:13) seperti gambaran umum pada The Samaya Seminyak Bali dan penilaian responden terhadap pernyataan-pernyataan yang diajukan dalam kuesioner.Data Kuantitatif, adalah data dalam bentuk angka yang dapat dinyatakan dan diukur dengan satuan hitung atau data kualitatif yang diangkakan. Angka yang dimaksud disini seperti data jumlah karyawan, dan skor jawaban kuisioner yang dilakukan pada The Samaya Seminyak Bali. Data primer adalah data yang diperoleh dari objek penelitian dan diolah lagi untuk digunakan (Sugiyono, 2014:308). Misalnya hasil jawaban kuisioner pengaruh Work-family conflict dan dukungan organisasi terhadap kepuasan kerja dan turnover 
intentionkaryawan The Samaya Seminyak Bali. Data sekunder adalah data yang diperoleh dari perusahaan yang sudah diolah oleh pihak lain. misalnya sejarah singkat hotel The Samaya Seminyak Bali, jumlah karyawan The Samaya Seminyak Bali dan struktur organisasiThe Samaya Seminyak Bali.

Populasi dalam penelitian ini adalah seluruh karyawan tetap The Samaya Seminyak Bali yang berjumlah 66 orang. Metode penentuan sampling yang digunakan dalam penelitian ini menggunakan teknik sampling jenuh/sensus yang mengambil seluruh populasi sebagai sampel penelitian (Supardi, 2011: 102). Sehingga seluruh anggota populasi yang berjumlah 66 orang karyawan dijadikan sebagai responden/sampel penelitian.Dalam suatu penelitian, pengumpulan data dilakukan dengan sistematis, cermat dan secara hati - hati sehingga data yang dikumpulkan harus relevan dengan masalah penelitian yang akan dijawab sebagai upaya menguji kebenaran hipotesis yang telah dirumuskan. Metode pengumpulan data yang digunakan adalah observasi, wawancara dan kuisioner.

Menurut (Sugiyono, 2014:455) validitas merupakan derajad ketepatan antara data yang sesungguhnya terjadi pada objek penelitian dengan data yang dapat dilaporkan oleh peneliti. Pengujian validitas dilakukan dengan menggunakan product moment dengan bantuan fasilitas Software Statistic Package for the Social Science (SPSS) for windows. Reliabilitas instrument diukur berdasarkan nilai alpha cronbach. Menurut Ghozali (2013:47) reliabilitas adalah alat untuk mengukur suatu kuesioner yang merupakan indikator dari variabel atau konstruk. Suatu kuesioner dinyatakan reliabel atau handal jika jawaban seseorang terhadap penyataan adalah konsisten atau stabil dari waktu ke waktu. Pengujian realiabilitas ini menggunakan metode statistik Cronbach Alpha $(\alpha)$. Suatu konstruk atau variabel dikatakan reliabel jika memberikan nilai Cronbach Alpha > 0,60 .

Dalam penelitian ini teknik analisis yang digunakan adalah teknik analisis jalur (path analysis). Ghozali (2013:249) mendefinisikan analisis jalur (path analysis) adalah perluasan dari analisis regresi linear berganda dalam memperkirakan hubungan kausalitas antara yang telah ditetapkan berdasarkan teori. Analisis jalur digunakan untuk menentukan hubungan antara tiga variabel atau lebih dalam mengkonfirmasi ataupun menolak hipotesis. Analisis jalur dikembangkan sebagai metode untuk mempelajari pengaruh, baik secara langsung maupun tidak langsung variabel bebas Work-family conflict dan dukungan organisasi terhadap variabel terikat kepuasan kerja dan turnover intention. Pada penelitian ini peneliti menggunakan diagram jalur anak panah dua arah yang menyatakan hubungan korelasi antara variabel eksogen (Riduwan dan Kuncoro, 2011:115).

\section{HASIL DAN PEMBAHASAN}

Responden penelitian digambarkan secara umum dengan menyajikan profilnya dilihat dari beberapa variabel demografi yaitu jenis kelamin, usia, dan pendidikan terakhir. Berdasarkan Tabel 2. dapat dilihat jumlah profil responden kuisioner yang diberikan peneliti dari jenis kelamin perempuanyaitu sebanyak 14 
persen dan laki-laki 86 persen.Berdasarkan Tabel 2. responden yang berjenis kelamin laki-laki sejumlah 57 orang sedangkan perempuan berjumlah 9 responden dengan persentase masing-masing 86 persen dan 14 persen. Menurut segi usia, responden yang mendominasi pengisian kuesioner penelitian adalah yang memiliki usia 36 - 40 tahunsebanyak 29 orang dengan persentase 44 persen, dari segi jabatan responden yang lebih dominan adalah responden yang memiliki jabatan Housekeeping dengan jumlah sebanyak 23 orang dengan persentase sebanyak 35 persen, dan dari segi lamanya bekerja didominasi oleh responden dengan masa kerja $\leq 10$ Tahun dengan jumlah sebanyak 56 orang dengan persentase sebanyak 85 persen.

Tabel 2.

Profil Responden

\begin{tabular}{|c|c|c|c|c|}
\hline No & Variabel & Klasifikasi & Jumlah & Persen $(\%)$ \\
\hline \multirow[t]{3}{*}{1} & Jenis Kelamin & Laki-laki & 57 & 86 \\
\hline & & Perempuan & 9 & 14 \\
\hline & & Total & 66 & 100 \\
\hline \multirow[t]{6}{*}{2} & Usia & $31-35$ & 11 & 17 \\
\hline & & $36-40$ & 29 & 44 \\
\hline & & $41-45$ & 16 & 24 \\
\hline & & $46-50$ & 7 & 11 \\
\hline & & $>51$ & 3 & 4 \\
\hline & & Total & 66 & 100 \\
\hline \multirow[t]{10}{*}{3} & Jabatan & General Manager & 1 & 1 \\
\hline & & Front Office & 11 & 17 \\
\hline & & House Keeping & 23 & 35 \\
\hline & & Food \& Beverage Product & 11 & 17 \\
\hline & & Food \& Beverage Service & 6 & 9 \\
\hline & & Security & 4 & 6 \\
\hline & & Accounting & 2 & 3 \\
\hline & & Engineering & 4 & 6 \\
\hline & & Therapist spa & 4 & 6 \\
\hline & & Total & 66 & 100 \\
\hline \multirow[t]{4}{*}{4} & Lama Bekerja & $\leq 10$ Tahun & 56 & 85 \\
\hline & & 11-20 Tahun & 9 & 14 \\
\hline & & $\geq 20$ Tahun & 1 & 1 \\
\hline & & Total & 66 & 100 \\
\hline
\end{tabular}

Sumber : Data Diolah, 2019

Hasil uji validitas instrumen penelitian disajikan pada Tabel 3, Tabel 3. menunjukkan bahwa seluruh indikator dalam variabelwork-family conflict, dukungan organisasi, kepuasan kerja dan turnover intention memiliki nilai Pearson Correlation yang lebih besar dari angka 0,30 sehingga seluruh indikator tersebut dikatakan telah memenuhi syarat validitas data.

Instrumen dikatakan reliabel untuk mengukur variabel bila berada di atas angka 0,60. Hasil pengujian reliabilitas instrumen dapat dilihat pada Tabel 4.

Berdasarkan Tabel 4. dapat dilihat bahwa ketiga variabel penelitian yaitu work-family conflict, dukungan organisasi, kepuasan kerja dan turnover intention memiliki koefisien cronbach's alphayang lebih besar dari angka 0,60 sehingga 
dapat dikatakan reliabel.Distribusi penilaian responden, mengenai work-family conflict $(\mathrm{X} 1)$ dapat dilihat pada Tabel 5.

Tabel 3.

Hasil Uji Validitas

\begin{tabular}{cccc}
\hline Variabel & Instrumen & Pearson Correlation & Keterangan \\
\hline Work-Family Conflict & X1.1 & 0,586 & Valid \\
(X1) & X1.2 & 0,612 & Valid \\
Xukungan Organisasi & X2.1 & 0,770 & Valid \\
(X2) & X2.2 & 0,882 & Valid \\
& X2.3 & 0,570 & Valid \\
& X2.4 & 0,792 & Valid \\
& X2.5 & 0,392 & Valid \\
& X2.6 & 0,768 & Valid \\
Kepuasan Kerja & X2.7 & 0,398 & Valid \\
(Y1) & Y1.1 & 0,351 & Valid \\
& Y1.2 & 0,953 & Valid \\
& Y1.3 & 0,735 & Valid \\
& Y1.4 & 0,836 & Valid \\
& Y1.5 & 0,574 & Valid \\
& Y2.1 & 0,743 & Valid \\
& Y2.2 & 0,828 & Valid \\
& Y2.3 & 0,807 & Valid \\
& & 0,798 & Valid \\
\hline
\end{tabular}

Sumber : Data Diolah, 2019

Tabel 4.

Hasil Uji Reliabilitas

\begin{tabular}{ccc}
\hline Variabel & Cronbach'sAlpha & Keterangan \\
Work-Family Conflict & 0,746 & Reliabel \\
Dukungan Organisasi & 0,738 & Reliabel \\
Kepuasan Kerja & 0,800 & Reliabel \\
Turnover Intention & 0,825 & Reliabel \\
\hline
\end{tabular}

Sumber : Data Diolah, 2019

Tabel 5. menjelaskan persepsi responden mengenai variabel work family coflict dapat dilihat secara keseluruhan memiliki nilai total rata-rata jawaban responden sebesar 3,86 yang masuk dalam kategori tinggi. Pernyataan pertama dengan skor nilai jawaban tertinggi sebesar 4,07 ini menunjukkan bahwa karyawan merasakan kesulitan untuk mengatur waktunya bersama keluarga dan pekerjaan sehingga hal itu menyumbang adanya work-family confict pada The Samaya Seminyak Bali. Maka dari itu pihak manajemen haruslah lebih sering 
untuk memperhatikan beban kerja yang akan diberikan kepada karyawan sehingga beban kerja tidak akan mengganggu waktu karyawan bersama keluarga.Distribusi penilaian responden, mengenai Dukungan Organisasi(X2) dapat dilihat pada Tabel 6.

Tabel 5.

Hasil Penilaian Responden atas Variabel Work-Family Conflict

\begin{tabular}{|c|c|c|c|c|c|c|c|c|}
\hline \multirow[b]{2}{*}{$\begin{array}{l}\mathbf{N} \\
\mathbf{0}\end{array}$} & \multirow[b]{2}{*}{ Pernyataan } & \multicolumn{5}{|c|}{ Jawaban } & \multirow[b]{2}{*}{$\begin{array}{l}\text { Rata- } \\
\text { rata } \\
\text { Skor }\end{array}$} & \multirow{2}{*}{$\begin{array}{l}\text { Kategor } \\
\text { i } \\
\text { Penilaia } \\
\text { n }\end{array}$} \\
\hline & & $\begin{array}{l}\text { ST } \\
\text { S }\end{array}$ & $\begin{array}{l}\mathbf{T} \\
\mathbf{S}\end{array}$ & $\mathbf{N}$ & $\mathbf{S}$ & SS & & \\
\hline 1 & $\begin{array}{l}\text { Saya merasa kesulitan untuk mengatur } \\
\text { waktu antara pekerjaan dengan } \\
\text { keluarga. }\end{array}$ & 0 & 7 & 3 & 34 & 22 & 4,07 & Baik \\
\hline 2 & $\begin{array}{l}\text { Saya merasa beban kerja yang } \\
\text { diberikan organisasi mengganggu } \\
\text { waktu berkumpul dengan keluarga. }\end{array}$ & 1 & 4 & 29 & 17 & 15 & 3,62 & Baik \\
\hline 3 & $\begin{array}{l}\text { Pekerjaan kantor sering saya kerjakan } \\
\text { di rumah sehingga mengganggu waktu } \\
\text { senggang bersama keluarga. }\end{array}$ & 2 & 4 & 12 & 29 & 19 & 3,89 & Baik \\
\hline & ariabel work-family conflict & & & & & & 3,86 & Baik \\
\hline
\end{tabular}

Tabel 6.

Hasil Penilaian Responden atas Variabel Dukungan Organisasi

\begin{tabular}{|c|c|c|c|c|c|c|c|c|}
\hline \multirow{2}{*}{ No } & \multirow{2}{*}{ Pernyataan } & \multicolumn{5}{|c|}{ Jawaban } & \multirow{2}{*}{$\begin{array}{l}\text { Rata- } \\
\text { rata } \\
\text { Skor }\end{array}$} & \multirow{2}{*}{$\begin{array}{l}\text { Kategori } \\
\text { Penilaian }\end{array}$} \\
\hline & & STS & TS & $\mathbf{N}$ & $\mathbf{S}$ & SS & & \\
\hline 1 & $\begin{array}{l}\text { Perusahaan menghargai kontribusi } \\
\text { saya dalam bekerja }\end{array}$ & 6 & 9 & 17 & 25 & 9 & 3,33 & $\begin{array}{l}\text { Cukup } \\
\text { Baik }\end{array}$ \\
\hline 2 & $\begin{array}{l}\text { Perusahaan sudah cukup memberi } \\
\text { pengakuan kerja ekstra terhadap } \\
\text { pekerjaan yang mampu saya } \\
\text { selesaikan dengan bekerja keras }\end{array}$ & 0 & 7 & 31 & 17 & 11 & 3,48 & Baik \\
\hline 3 & $\begin{array}{l}\text { Perusahaan menanggapi dengan baik } \\
\text { jika saya mempunyai keluhan. }\end{array}$ & 1 & 15 & 3 & 41 & 6 & 3,54 & Baik \\
\hline 4 & $\begin{array}{l}\text { Perusahaan akan memberikan } \\
\text { bantuan bila saya menghadapi } \\
\text { kesulitan. }\end{array}$ & 1 & 1 & 22 & 11 & 31 & 4,06 & Baik \\
\hline 5 & $\begin{array}{l}\text { Perusahaan peduli dengan } \\
\text { kesejahteraan saya. }\end{array}$ & 0 & 8 & 18 & 22 & 18 & 3,75 & Baik \\
\hline 6 & $\begin{array}{l}\text { Perusahaan memberikan perhatian } \\
\text { lebih apabila saya bekerja dengan } \\
\text { baik. }\end{array}$ & 1 & 1 & 10 & 32 & 22 & 4,11 & Baik \\
\hline 7 & $\begin{array}{l}\text { Perusahaan akan menunjukan } \\
\text { prestasi saya kepada karyawan } \\
\text { lainnya apabila telah mencapai target } \\
\text { pekerjaan. }\end{array}$ & 1 & 6 & 4 & 40 & 15 & 3,94 & Baik \\
\hline Var & abel Dukungan Organisasi & & & & & & 3,74 & Baik \\
\hline
\end{tabular}

Sumber : Data Diolah, 2019 
Tabel 6. menjelaskan persepsi responden mengenai variabel Dukungan Organisasidapat dilihat secara keseluruhan memiliki nilai total rata-rata jawaban responden sebesar 3,74 yang masuk dalam kategori baik. Pernyataan keenam yaitu "Perusahaan memberikan perhatian lebih apabila saya bekerja dengan baik" memiliki skor nilai jawaban tertinggi sebesar 4,11 dan skor terendah sebesar 3,33 berada pada pernyataan pertama "Perusahaan menghargai kontribusi saya dalam bekerja.". Maka dari itu pihak manajemen harus lebih memperhatikan kotribusi setiap karyawannya dengan memberikan penghargaan lebih bagi karyawan yang telah berkontribusi lebih pada perusahaan.Distribusi penilaian responden, mengenai Kepuasan Kerja(Y1) dapat dilihat pada Tabel 7. sebagai berikut.

Tabel 7.

Hasil Penilaian Responden atas Variabel Kepuasan Kerja

\begin{tabular}{|c|c|c|c|c|c|c|c|c|}
\hline \multirow{2}{*}{ No } & \multirow{2}{*}{ Pernyataan } & \multicolumn{5}{|c|}{ Jawaban } & \multirow{2}{*}{$\begin{array}{l}\text { Rata- } \\
\text { rata } \\
\text { Skor }\end{array}$} & \multirow{2}{*}{$\begin{array}{l}\text { Kategori } \\
\text { Penilaian }\end{array}$} \\
\hline & & STS & TS & $\mathbf{N}$ & $\mathbf{S}$ & SS & & \\
\hline 1 & $\begin{array}{l}\text { Gaji yang saya terima sudah } \\
\text { sesuai dengan beban kerja yang } \\
\text { diberikan perusahaan. }\end{array}$ & 5 & 9 & 15 & 25 & 12 & 3,45 & Baik \\
\hline 2 & $\begin{array}{l}\text { Pekerjaan yang saya terima sudah } \\
\text { sesuai dengan keterampilan yang } \\
\text { saya miliki. }\end{array}$ & 0 & 5 & 28 & 21 & 12 & 3,60 & Baik \\
\hline 3 & $\begin{array}{l}\text { Kebijakan promosi (kenaikan } \\
\text { pangkat atau jabatan) di tempat } \\
\text { kerja saya sudah sesuai dengan } \\
\text { kinerja masing-masing karyawan }\end{array}$ & 0 & 14 & 2 & 44 & 6 & 3,64 & Baik \\
\hline 4 & $\begin{array}{l}\text { Atasan memberikan penghargaan } \\
\text { terhadap keberhasilan saya dalam } \\
\text { menjalankan tugas. }\end{array}$ & 0 & 1 & 20 & 12 & 33 & 4,17 & Baik \\
\hline 5 & $\begin{array}{l}\text { Saya memiliki hubungan } \\
\text { komunikasi yang terjalin dengan } \\
\text { baik diantara sesama rekan kerja }\end{array}$ & 0 & 6 & 17 & 29 & 14 & 3,77 & Baik \\
\hline Var & abel Kepuasan Kerja & & & & & & 3,73 & Baik \\
\hline
\end{tabular}

Sumber : Data Diolah, 2019

Tabel 7. menjelaskan persepsi responden mengenai variabel Kepuasan Kerja dapat dilihat secara keseluruhan memiliki nilai total rata-rata jawaban responden sebesar 3,66 yang masuk dalam kategori baik. Pernyataan keempat yaitu "Atasan memberikan penghargaan terhadap keberhasilan saya dalam menjalankan tugas" memiliki skor nilai jawaban tertinggi sebesar 4,17 dan skor terendah sebesar 3,45 berada pada pernyataan pertama "Gaji yang saya terima sudah sesuai dengan beban kerja yang diberikan perusahaan.". Maka dari itu pihak manajemen harus lebih memperhatikan jumlah imbalan yang diterima oleh karyawannya, apakah sudah sesuai dengan beban kerjanya atau tidak. Rekapitulasi penilaian responden mengenai Organizational Citizenship Behavior (Y) dapat dilihat pada Tabel 8.

Tabel 8. menjelaskan persepsi responden mengenai variabel turnover intention dapat dilihat secara keseluruhan memiliki nilai total rata-rata jawaban responden sebesar 3,56 yang masuk dalam kategori baik. Pernyataan ketiga yaitu"Saya tidak bisa berkembang apabila masih menekuni profesi saya saat ini." 
dengan skor nilai jawaban tertinggi sebesar 3,74 dan skor terendah sebesar 3,47 berada pada pernyataan kedua yaitu "Mencari pekerjaan baru di perusahaan lain merupakan keinginan saya saat ini.".

Tabel 8.

Hasil Penilaian Responden atas Variabel Turnover Intention

\begin{tabular}{|c|c|c|c|c|c|c|c|c|}
\hline \multirow[b]{2}{*}{ No } & \multirow[b]{2}{*}{ Pernyataan } & \multicolumn{5}{|c|}{ Jawaban } & \multirow{2}{*}{$\begin{array}{l}\text { Rata- } \\
\text { rata } \\
\text { Skor }\end{array}$} & \multirow{2}{*}{$\begin{array}{l}\text { Kategori } \\
\text { Penilaian }\end{array}$} \\
\hline & & STS & TS & $\mathbf{N}$ & $\mathbf{S}$ & SS & & \\
\hline 1 & $\begin{array}{l}\text { Saya tidak ingin bekerja lagi di } \\
\text { perusahaan ini. }\end{array}$ & 2 & 6 & 21 & 33 & 4 & 3,47 & Baik \\
\hline 2 & $\begin{array}{l}\text { Mencari pekerjaan baru di } \\
\text { perusahaan lain merupakan } \\
\text { keinginan saya saat ini. }\end{array}$ & 1 & 9 & 24 & 22 & 10 & 3,47 & Baik \\
\hline 3 & $\begin{array}{l}\text { Saya tidak bisa berkembang } \\
\text { apabila masih menekuni profesi } \\
\text { saya saat ini. }\end{array}$ & 4 & 8 & 4 & 35 & 15 & 3,74 & Baik \\
\hline Vai & abel Turnover Intention & & & & & & 3,56 & Baik \\
\hline
\end{tabular}

Nilai Kolmogorov Sminarnov (K-S) sebesar 0,144, sedangkan nilai Asymp. Sig. (2-tailed) sebesar 0,163. Hasil tersebut mengindikasikan bahwa model persamaan regresi 1 tersebut berdistribusi normal karena nilai Asymp. Sig. (2tailed) 0,163 lebih besar dari nilai alpha 0,05. Nilai Kolmogorov Sminarnov (K-S) sebesar 0,059, sedangkan nilai Asymp. Sig. (2-tailed) sebesar 0,200. Hasil tersebut mengindikasikan bahwa model persamaan regresi 2 tersebut berdistribusi normal karena nilai Asymp. Sig. (2-tailed) 0,200 lebih besar dari nilai alpha 0,05.

Nilai tolerance dan VIF dari variabel work-family conflict dan dukungan organisasi menunjukkan nilai tolerance lebih besar dari $10 \%$ dan nilai VIF lebih kecil dari 10 yang berarti model persamaan regresi bebas dari multikolinearitas. Nilai tolerance dan VIF dari variabel Work-Family Conflict, Dukungan Organisasi dan Kepuasan Kerja menunjukkan nilai tolerance lebih besar dari 10\% dan nilai VIF lebih kecil dari 10 yang berarti model persamaan regresi bebas dari multikolinearitas.

Nilai Sig. dari variabel Work-Family Conflict sebesar 0,778, dan variabelDukungan Organisasisebesar 0,290. Hasil tersebut menunjukkan bahwa seluruh variabel terbebas dari masalah heteroskedastisitas karena nilai Sig. > 0,05. Nilai Sig. dari variabel Work-Family Conflict sebesar 0,287, dan variabelDukungan Organisasisebesar 0,098 dan variabel Kepuasan Kerja sebesar 0,059 . Hasil tersebut menunjukkan bahwa seluruh variabel terbebas dari masalah heteroskedastisitas karena nilai Sig. > 0,05.

Pengujian persamaan path dilakukan untuk melihat pengaruh work-family conflict dan dukungan organisasi terhadap turnover intention melalui variabel kepuasan kerja yang dilakukan dengan menggunakan program SPSS. Berdasarkan hasil olah data, maka hasil analisis jalur persamaan uji regresi I disajikan dalam Tabel 9. dan hasil analisis jalur persamaan uji regresi II disajikan dalam Tabel 10. 
Tabel 9.

Hasil Analisis Jalur Persamaan Regresi 1

\begin{tabular}{lccr}
\hline \multicolumn{1}{c}{ Variabel } & Koefisien Regresi & T & Signifikansi \\
\hline Work-Family Conflict (X1) & $-0,064$ & $-0,507$ & 0,041 \\
Dukungan Organisasi (X2) & 0,243 & 1,936 & 0,007 \\
F Hitung & & & $\mathbf{1 1 , 8 7 7}$ \\
Signifikansi & & & $\mathbf{0 , 0 0 1}$ \\
R1 & & & $\mathbf{0 , 8 3 7}$ \\
Adjusted R1 Square & & $\mathbf{0 , 7 2 6}$ \\
\hline \multicolumn{1}{l}{ Sumber : Data Diolah, 2019 } & &
\end{tabular}

Hasil perhitungan pengaruh error (Pei), jadi didapatkan hasil standar error variabel work-family conflict dan dukungan organisasi $\left(\mathrm{Pe}_{1}\right)$ sebesar 0,523 dan hasil standar error variabel work-family conflict, dukungan organisasi dan kepuasan kerja $\left(\mathrm{Pe}_{2}\right)$ sebesar 0,628.

Nilai determinasi total sebesar 0,892 mempunyai arti bahwa sebesar 89,2\% variasi Turnover Intention dipengaruhi oleh variasi work-family conflict, dukungan organisasi dan kepuasan kerja, sedangkan sisanya sebesar 10,8\% djelaskan oleh faktor lain yang tidak dimasukkan ke dalam model.

Berdasarkan hasil analisis pengaruh Work-Family Conflict terhadap Kepuasan Kerja diperoleh nilai Sig. $t$ sebesar 0,041 dengan nilai koefisien beta 0,064 Nilai Sig. t 0,041<0,05 mengindikasikan bahwa $\mathrm{H}_{0}$ ditolak dan $\mathrm{H}_{1}$ diterima. Hasil ini mempunyai arti bahwa Work-Family Conflict berpengaruh negatif terhadap Kepuasan Kerja.Berdasarkan hasil analisis Pengaruh Dukungan Organisasi terhadap Kepuasan Kerja diperoleh nilai Sig. t sebesar 0,007 dengan nilai koefisien beta 0,243. Nilai Sig. t 0,007<0,05 mengindikasikan bahwa $\mathrm{H}_{0}$ ditolak dan $\mathrm{H}_{1}$ diterima. Hasil ini mempunyai arti bahwa Dukungan Organisasiberpengaruh positif terhadap Kepuasan Kerja.

Berdasarkan hasil analisis pengaruh Work-Family Conflict terhadap Turnover Intention diperoleh nilai Sig. $\mathrm{t}$ sebesar 0,035 dengan nilai koefisien beta 0,267. Nilai Sig. t $0,035<0,05$ mengindikasikan bahwa $\mathrm{H}_{0}$ ditolak dan $\mathrm{H}_{1}$ diterima. Hasil ini mempunyai arti bahwa Work-Family Conflict berpengaruh positif terhadap Turnover Intention.Berdasarkan hasil analisis pengaruh Dukungan Organisasi terhadap Turnover Intention diperoleh nilai Sig. t sebesar 0,043 dengan nilai koefisien beta $-0,251$. Nilai Sig. $t \quad 0,043<0,05$ mengindikasikan bahwa $\mathrm{H}_{0}$ ditolak dan $\mathrm{H}_{1}$ diterima. Hasil ini mempunyai arti bahwa Dukungan Organisasi berpengaruh negatif terhadap Turnover Intention.Berdasarkan hasil analisis pengaruh Kepuasan Kerja terhadap Turnover Intention diperoleh nilai Sig. $\mathrm{t}$ sebesar 0,005 dengan nilai koefisien beta $-0,080$. Nilai Sig. t 0,005<0,05 mengindikasikan bahwa $\mathrm{H}_{0}$ ditolak dan $\mathrm{H}_{1}$ diterima. Hasil ini mempunyai arti bahwa Kepuasan Kerja berpengaruh negatif terhadap Turnover Intention.

Dapat disimpulkan bahwa variabel work-family conflict dan dukungan organisasi memiliki pengaruh langsung terhadap turnover intention dan pengaruh tidak langsung melalui kepuasan kerja. Besarnya koefisien pengaruh tidak langsung dapat dihitung dengan mengalikan koefisien jalur dari work-family 
conflict dan dukungan organisasi ke kepuasan kerja dengan koefisien jalur dari kepuasan kerja ke turnover intention sebesar $(-0,064) \times(-0,080)=0,005$ untuk pengaruh tidak langsung variabel work-family conflict terhadap turnover intention dan sebesar $(0,243) \times(-0,080)=-0,019$ untuk pengaruh tidak langsung variabel dukungan organisasiterhadap turnover intention.

\section{SIMPULAN}

Hasil analisis dan pembahasan tentang hubungan antar variabel penelitian memberikan simpulan penelitian sebagai berikut. 1) Variabel work-family conflict berpengaruh negatif dan signifikan terhadap kepuasan kerja karyawan The Samaya Seminyak Bali. Hasil tersebut memperlihatkan bahwa semakin meningkatnya Work-Family Conflict pada karyawan The Samaya Seminyak Balimaka akan menurunkan kepuasan kerja yang dirasakan karyawan. 2) Variabel Dukungan Organisasiberpengaruh positif terhadap Kepuasan Kerja. Hal ini memiliki makna bahwa semakin banyak dukungan organisasi yang diberikan terhadap karyawan, maka akan semakin tinggi pula kepuasan kerja yang ditunjukkan oleh karyawan The Samaya Seminyak Bali. Begitu pula sebaliknya, semakin sedikit dukungan organisasi yang diberikan kepada karyawan maka semakin rendah tingkat kepuasan kerja karyawan pada The Samaya Seminyak Bali. 3) Variabel Work-Family Conflict berpengaruh positif terhadap Turnover Intention. Hasil tersebut berarti tingginya work family conflict yang dirasakan oleh karyawan dapat mempengaruhi keinginan keluar dari perusahaan, sehingga semakin tinggi work family conflict maka semakin tinggi pula turnover intention yang dirasakan karyawan 4) Variabel Dukungan Organisasi berpengaruh negatif terhadap Turnover Intention. Hasil tersebut berarti bahwa dukungan organisasi yang tinggi cenderung menurunkan keinginan karyawan untuk meninggalkan perusahaan. 5)Variabel Kepuasan Kerja berpengaruh negatif terhadap Turnover Intention. Hasill ini menunjukkan bahwa semakin tinggi tingkat kepuasan kerja karyawan maka semakin rendah turnover intention yang dirasakan karayawan pada perusahaan tersebut.

Saran yang dapat diberikan berdasarkan hasil analisis dan pembahasan adalah sebagai berikut. 1) Pihak manajemen The Samaya Seminyak Bali haruslah lebih sering untuk memperhatikan beban kerja yang akan diberikan kepada karyawan sehingga beban kerja tidak akan mengganggu waktu karyawan bersama keluarga2) Manajemen The Samaya Seminyak Bali harus lebih memperhatikan kontribusi setiap karyawannya dengan memberikan penghargaan lebih bagi karyawan yang telah berkontribusi lebih pada perusahaan 3) Pihak pimpinan The Samaya Seminyak Bali harus lebih memperhatikan jumlah imbalan yang diterima oleh karyawannya, apakah sudah sesuai dengan beban kerjanya atau tidak.4)Bagi peneliti selanjutnya, diharapkan untuk melakukan penelitian dengan cakupan yang lebih luas, menambah variabel-variabel lain di luar penelitian ini, serta diharapkan mampu menambah referensi atau sumber yang lebih banyak terhadap variabel yang akan diteliti. 


\section{REFERENSI}

Abdillah, Faud. 2012. Hubungan kohevitas kelompok dengan intensi turnover pada karyawan. Journal of Social and Industrial Psychology. 1(2), pp: 5258 .

Adeloka, B 2010. Interferences between work and family among male and female executives in Nigeria. African Journal of Business Management. 4 (6). pp: 1070.

Adeniji, Anthonia Adenike. 2011. Organizational Climate and Job Satisfaction among Academic Staff Insome Selected Private Universities in Southwest Nigeria. Business Intelligence Journal, 4 (1) 151-156.

Afrilia, L.D., dan H.N. Utami. 2018. Pengaruh Work-Family Conflict Terhadap Kepuasan Kerja Dan Kinerja (Studi Pada Karyawan Wanita Rumah Sakit Permata Bunda Malang). Jurnal Administrasi Bisnis (JAB). 55(2): 48-56

Amelia, Anisah. 2010. Pengaruh Work-to-Family Conflict dan Family-to-Work Conflict Terhadap Kepuasan dalam Bekerja, dan Kinerja Karyawan. Jurnal Ekonomi dan Bisnis. Vol 4. No. 3. Hal. 201-219.

Anafarta, Nilgun. 2011. The Relationship between Work-family conflict and job satisfaction A structural equation model (SEM) Approach. International Journal of Bussiness and Management. Vol.6, No. 4.

Ardana, I Komang., Ni Wayan Mujiati, I Wayan Mudiartha Utama. 2012. Manajemen Sumber Daya Manusia. Edisi Pertama. Yogyakarta: Graha Ilmu.

Ariana, I.W.J. dan I.G. Riana. 2016. Pengaruh Work-Family Conflict, Keterlibatan Kerja Dan Stres Kerja Terhadap Kepuasan Kerja Karyawan. EJurnal Manajemen Unud. 5(7): 4630 - 4659

Azeem, S. M. 2010. Job Satisfaction and Organizational Commitment among Employees in the Sultanate of Oman. Journal Pyschology Scientific Research, 1. (4), pp: $295-299$.

Blomme, Robert.J, Arjan Van Rheede, Debbie M. Tromp. 2010. Work-family conflict as a cause for Turnover intentions in The Hospitality Industry. Tourism and Hospitality Research. Vol. 10, No. 4. pp 269-285.

Buhali, G. A., Margaretha, M. 2013. Pengaruh Work family conflict terhadap Komitmen Organisasi Kepuasan Kerja sebagai Variabel Mediasi. Jurnal Manajemen. 13(1). 
Christine W.S., Megawati Oktorina., Indah Mula. 2010. Pengaruh Konflik Pekerjaan Dan Konflik Keluarga Terhadap Kinerja Dengan Konflik Pekerjaan Keluarga Sebagai Intervening Variabel (Studi Pada Dual Career Couple Di Jabodetabek). Jurnal Manajemen Dan Kewirausahaan, 12 (2), Pp: 121-132

Dawley, D., Houghton, J.D. \& Bucklew, N.S. 2010. Perceived organizational support and turnover intention: The mediating of personal sacrifice and job fit. Journal of Social Psychology, Vol.3, No.150, pp.238 - 257.

Dewi, N.P.K.C. dan A.A.S.K. Dewi. 2018. Pengaruh Dukungan organisasional Dan Keadilan Imbalan Terhadap Kepuasan Kerja Pada Sopir Koptax Ngurah Rai Bali. E-Jurnal Manajemen Unud. 7(2): 1050-1079

Dewi, I.G.A.D.S., dan I.W.M.Utama. 2015. Pengaruh Emotional Intelligence Leaders, Pemberdayaan Karyawan, Dan Dukungan organisasional Terhadap Kepuasan Kerja. E-Jurnal Manajemen Unud. 4(6): 1676-1699

Dhyana, I.G.A.K. dan I.G.A.D. Adnyani. 2018. Pengaruh Gaya Kepemimpinan, Pemberdayaan Karyawan Dan Dukungan organisasional Terhadap Kepuasan Kerja Karyawan. E-Jurnal Manajemen Unud. 7(7): 3594-3622

Dockel, Andreas. 2006. The effect of retention factors on organizational commitment: an investigation of high technology employee. SA Journal of Human Resource Management. Vol. 4. No. 28. pp: 20-2

Ehsani, M., Sofdel, H. S., Amiri, M., Masrur, F. F., \& Hossini, R. N. 2013. Relationship between perceived organizational support with job satisfaction and organizational commitment of sports departments staff. International Journal of Sport Studies, Vol.3, No.12. pp.1302-06.

Fahrizal., dan I.W.M. Utama. 2017. Pengaruh Persepsi Dukungan organisasional Terhadap Komitmen Organisasional Dan Turnover Intention Karyawan Hotel Kajane Mua Ubud. E-Jurnal Manajemen Unud. 6(10): 5405-5431

Frye, N.K. and J.A. Breaugh. 2004. Family-friendly Policies, Supervisor Support, Work-family conflict, Family-work Conflict, and Satisfaction: A Test of a Conceptual Model. Journal of Business and Psychology. 19(2), 197-220.

Fuller, B., Barnet, T., Hester, K., and Relyea, C. 2003. A Social Idenity Perspective on The Relationship Between Perceived organizational support and Organizational Commitment. Journal of Social Psychology. 143(6): 789-791. 
Ghani, Nik Azida Abd and Shah Raja Teuku Ahmad Badrul Hussin. 2009. Antecedents of Perceived Organizational Support. Canadian Social Science, 5 (6), pp: 121-130.

Ghozali, Imam. 2013. Aplikasi Analisis Multivariate dengan Program IBM SPSS 2.1, Edisi. Ketujuh, Semarang: Badan Penerbit UNDIP.

Ghayyur, Muhammad dan Waseef Jamal. 2012. Work-family conflicts: A Case of Employees Turnover intention. International Journal of Social Science and Humanity. Vol. 2, No.3.

Ghosh, Piyali et al, 2013. Who stays with you? Factors predicting employees' intention to stay. International Journal of Organizational Analysis. 21 (3). 288-312

Gliselli, Richard F., Joseph, M., Lopa, La., Bai, Billy. 2001. Job satisfaction, life satisfaction, and turnover intent among food-service managers. The Cornell Hotel and Restaurant Administration Quarterly, 42(2), 28-37

Gupta, A. A., Vohra, N., and Bhatnagar, D. 2010. Perceived organizational support and Organizational Commitment. The Mediational Influence of Psychological Well-Being. Journal of Business and Management, 16(2): 105-124

Harnoto. 2002. Manajemen Sumber Daya Manusia. Jakarta :Prehallindo

Islam, T., dan Khan, S.R. 2012. Turnover intention: the influence of organizational learning culture and multi foci citizenship behaviors. MiddleEast Journal of Scientific Research 12 (5). pp: 650-661.

Ivancevich, J. M., Konopaske R., and Matteson M, T. 2006. Perilaku dan Manajemen Organisasi Edisi Ketujuh. Jakarta: Erlangga.

Jimad, Habibullah, 2011, Kepuasan Kerja, Komitmen Organisasi, Dan Intensi Turnover. Jurnal Bisnis \& Manajemen. Volume 7. No.2 155-163.

Kuo, Y.K., Su, Y.Y. \& Chang, B.L. 2015. The Study on Relationships of Perceived Organizational Support and Job Satisfaction in Taiwan Hospitality Service Industry. In Managing Intellectual Capital and Innovation for Sustainable and Inclusive Society. Bary Italy.

Lai, Ming-Cheng, Chen, Yen-Chun. 2012. Self Efficacy, Effort, Job Perfomance, Job Statifaction, and Turnover intention: The Effect of Personal Characteristic on Organization Performance. International Journal of Innovation, Management and Technology. 3(4). pp: 387-391. 
Laksmi, Nimas Ayu Putri dan Cholichul Hadi. 2012. Hubungan antara Konflik Peran Ganda(Work family conflict) dengan Kepuasan Kerja pada Karyawati bagian Produksi PT.X. Jurnal Psikologi Industri dan Organisasi. Vol.1, No.2.

Lathifah, Ifah dan Abdul Rohman. 2014. The Influence of Work-family conflict on Turnover intentions with Job Satisfaction as an Intervening Variable on Public Accountant Firms in Indonesia. International Journal of Research in Business and Technology. Vol.5, No.2. pp 617-625.

Maertz, C.P., Griffeth, R.W., Campbell, N.S. and Allen, D.G. 2007. The effects of perceived organizational support and perceived supervisor support on employee turnover. Journal of Organizational Behavior. Vol. 28, pp. 105975 .

Mahdi, A, F., Zaid, M. M., Roslan, M., Nor, M., Sakat, H.A, and Naim, A. S. A. 2012. The relationship between job satisfaction and turnover intention. American Journal of Applied Sciences. Vol. 9 (9): 1518-1526.

Moorhead, G., dan Griffin, R.W. 2013. Perilaku Organisasi: Manajemen Sumber Daya Manusia dan Organisasi Edisi Kesembilan. Jakarta: Salemba Empat.

Nandini, Nurhasmadiar dan Thinni Nurul Rochmah. 2013. Penyebab Turnover intention pada Pegawai Instalasi Gizi Rumah Sakit PHC Surabaya. Jurnal Administrasi Kesehatan Indonesia. 1 (3), pp: 272-279.

Nasution, Wendi Amsuri, 2009, Pengaruh Kepuasan Kerja Karyawan Terhadap Intensi Turnover pada Call Center Telkomsel Di Medan, Jurnal Mandiri Volume 4, Nomor 1.

Newman, A. 2015. The effects of Perceived organizational support, perceived supervisor support and intra-organizational network resources on Turnover intention: A study of Chinese employees in multinational enterprises. Journal Personnel Review, 41(1): 56-72

Ngadiman, Munawar Muchlish, dan Nurainun Bangun. 2014. Prinsip Pengendalian, Ambiguitas Peran, Konflik Peran dan Kinerja Karyawan Serta Keinginan Berpindah Kerja(Studi Empiris pada Profesi Dosen di DKI Jakarta). Journal of The Academy of Marketing Science.

Novliadi, F. 2007. Intensi Turnover Karyawan ditinjau dari Budaya Perusahaan dan Kepuasan Kerja. Makalah Universitas Sumatra Utara, P. 7.

Pathak, D. 2012. Role of perceived organizational support on stress-satisfaction relationship : An empirical study. Asian Journal of Management Research, Vol.3, No.1, pp.153 - 177. 
Perryer, C., Jordan, C., Firns, I., and Travaglione, A. 2010. Predicting Turnover intention, The Interactive Effects of Organizational Commitment and Perceived organizational support. Manegement Research Review, 33(9): 911-923

Retnaningrum, A,K., dan M. Al Musadieq. 2016. Pengaruh Work-Family Conflict Terhadap Kepuasan Kerja Dan Kinerja (Studi pada perawat wanita RSUD Wonosari Yogyakarta). Jurnal Administrasi Bisnis (JAB). 36(1): 72-81

Riduwan dan Engkos Achmad Kuncoro. 2011. Cara Menggunakan dan Memaknai Analisis Jalur (Path Analysis). Bandung: Alfabeta.

Riduwan dan Sunarto. 2012. Pengantar Statistika Untuk Penelitian Pendidikan, Sosial, Ekonomi dan Bisnis. Bandung: Alfabeta.

Rindi Nurlaila Sari. 2014. Pengaruh Kepuasan Kerja, Stres Kerja Dan Komitmen Organisasi Terhadap Turnover intention(Pada Hotel Ibis Yogyakarta). Skripsi Fakultas Ekonomi Universitas Negeri Yogyakarta.

Robbins, S.P, dan Judge. 2008. Perilaku Organisasi. Jakarta: Salemba Empat.

Luthans, F. 2006. Prilaku Organisasi.Edisi ke 10.Andi.Yogyakarta.

Meyer, John P. Herscovith L. 2001. Commitment in the workplace : toward general model. Human Resource Management Review. Vol. 11. pp: 299326.

Salleh, R., Nair, M.S., dan Harun, H. 2012. Job satisfaction, organizational commitment, and turnover intention: a case study on employees of retail company in malaysia. World Academy of Science, Engineering and Technology, 72: 2012: 2022.

Sartika, Dwi. 2014. Pengaruh Kepuasan Kerja dan Gaya Kepemimpinan Transformasional Terhadap Keinginan Keluar Karyawan dengan Komitmen Organisasi Sebagai Variabel Mediasi (Studi Kasus di CV. Putra Tama Jaya). Management Analysis Journal. 3(2), pp: 1-11.

Satriya, M.G.R. 2018. Pengaruh Persepsi Dukungan organisasional Terhadap Intensi Turnover pada Karyawan Layoff Survivor. Jurnal POSTOI Universitas Airlangga. Pp:1-15

Setiawan, I Nyoman Agus. 2016. Pengaruh Job Insecurity Terhadap Kepuasan

Kerja Dan Turnover intention Pada Karyawan Legian Village Hotel. E-Jurnal Manajemen Unud, 5(8), h: 4983-5012 
Soeharto. Triana N. E. D. 2010. Konflik Pekerjaan-Keluarga Dengan Kepuasan Kerja : Metaanalisis. Jurnal Psikologi, 37(1), Pp 189 - 194

Sugiyono. 2014. Metode Penelitian Pendidikan Pendekatan Kuantitatif, Kualitatif Dan $R \& D$. Bandung: Alfabeta.

Supardi. 2011. Metode Penelitian Ekonomi dan Bisnis. Yogyakarta: UII Press.

Tariana, I.W.A., dan I.M.A. Wibawa. 2016. PERAN Mediasi Kepuasan Kerja Dalam Pengaruh Work Family Conflict Dan Turnover Intention Pada Karyawan Wanita. E-Jurnal Manajemen Unud. 5(9):5433-5461

Tintami, Lila, Dr. Ari Pradhanawati, M.S, Dr. Hari Susanto N., M.Si. 2012. Perngaruh Budaya Organisasi Dan Gaya Kepemimpinan Transformasional Terhadap Kinerja Karyawan Melalui Disiplin Kerja Pada Karyawan Harian STK Megawon II PT. Djarum Kudus, Diponogoro Journal Of Social And Politic. 1(1). pp: 1-8.

Ucho, A., M Kavga, T., and Onyishi, Ike E. 2012. Job Satisfaction, Gender, Tenure, and Turnover Intantion among Civil Servants in Benue State. Interdiciplinary Journal of Contempory Reseach in Business. 3 (11), pp: 378-387.

Wulandari, I.A.D. dan I.G.A.D. Adnyani. 2016. Pengaruh Work Family Conflict Terhadap Turnover Intention Melalui Mediasi Kepuasan Kerja Pada Hotel Grand Inna Kuta. E-Jurnal Manajemen Unud. 5(10): 6146-6173

Yih, W.W. \& Htaik, S. 2011. The Impact of Percieved Organisational support, Job Satisfaction, and Organizational Commitment on Job Performance in Hotel Industry. The 11th International DSI and the 16th APDSI Joint Meeting, Vol.3.

Yucel, I. 2012. Examining the Relationship among Job Satisfaction, Organizational Commitment, and Turnover intention: An Empirizal Study. International Journal of Business and Management, 7 (20), pp:44-58.

Zaffane, Rachid. 2003. Understanding Employee Turnover : The Need For a Contingency Approach. International Journal of Manpower. 15 (9) : 1-14. 